\title{
ASPEK HUKUM PEMBERHENTIAN PEGAWAI NEGERI SIPIL BERDASARKAN PERATURAN PEMERINTAH NOMOR 30 TAHUN 2019 TENTANG PENILAIAN KINERJA PEGAWAI NEGERI SIPIL
}

\author{
Iwan Permadi
}

Fakultas Hukum Universitas Brawijaya

Jalan MT. Haryono No.169 Malang, Jawa Timur - Indonesia

Email: hukum@ub.ac.id

\begin{abstract}
Performance appraisal of civil servants as stipulated in article 77 number (6) of Law Number 5 of 2014 concerning State Civil Apparatus, this article states that a civil servant whose performance evaluation is not in accordance with the established targets is subject to sanctions in the form of administrative sanctions until dismissal. Basically, the performance of civil servants is the result and assessment of work carried out by civil servants in quality and quantity that has been achieved by a civil servant in carrying out the duties, authorities, obligations and responsibilities that have been given. This changes the paradigm that has been formed so far that being a civil servant is impossible to be dismissed, and a civil servant is not an office employee who is assessed based on performance appraisal, from that background we formulate the issue What is the legis ratio of dismissal of civil servants based on performance appraisal in PP Number 30 of 2019 concerning work evaluation? and What are the legal implications of the dismissal of civil servants based on performance appraisal in PP Number 30 of 2019 concerning Performance Appraisal.
\end{abstract}

Keywords: Assessment, Performance, Civil Servants

\section{ABSTRAK}

Penilaian kinerja PNS diatur pasal 77 angka (6) Undang-Undang Nomor 5 Tahun 2014 tentang Aparatur Sipil Negara menyebutkan bahwa seorang PNS yang penilaian kinerjanya tidak sesuai target yang telah ditetapkan maka dikenakan sanksi berupa sanksi administratif hingga pemberhentian. Pada dasarnya kinerja PNS merupakan hasil dan penilaian kerja yang dilakukan oleh PNS secara kualitas dan kuantitas yang telah dicapai oleh seseorang PNS dalam melaksanakan tugas, kewenangan, kewajiban dan tanggung jawab yang telah diberikan. Hal ini merubah paradigma yang selama ini telah terbentuk bahwa menjadi seorang PNS mustahil untuk dapat diberhentikan, dan seorang PNS bukanlah seorang pegawai kantoran yang dinilai berdasarkan penilaian kinerja, dari latar belakang itulah maka kami merumuskan masalah Apa ratio legis dari pemberhentian PNS berdasarkan penilaian kinerja dalam PP Nomor 30 Tahun 2019 tentang Penilaian Kerja? Serta Apa implikasi hukum dari pemberhentian PNS berdasarkan penilaian kinerja dalam PP Nomor 30 Tahun 2019 tentang Penilaian Kinerja.

Kata kunci: Penilaian, Kinerja, Pegawai Negeri Sipil

\section{PENDAHULUAN}

Penyelenggaraan pembangunan nasional, dapat ditinjau berdasarkan kinerja dari Aparatur Sipil Negara (ASN). Dimana Pegawai Negeri Sipil (PNS) sebagai inti penggeraknya. Dalam Penjelasan Umum atas Undang-Undang Nomor 5 Tahun 2014 tentang Aparatur Sipil Negara (UU ASN) menyatakan bahwa dalam rangka mencapai tujuan nasional sebagaimana tercantum dalam alinea ke-4 Pembukaan Undang-Undang Dasar Negara Republik Indonesia Tahun 1945 (UUD 1945), diperlukan ASN yang professional, bebas dari intervensi politik, 
bersih dari praktik korupsi, kolusi dan nepotisme, mampu menyelenggarakan pelayanan publik bagi masayarakat dan mampu menjalankan peran sebagai perekat persatuan dan kesatuan bangsa berdasarkan Pancasila dan UUD 1945. Peningkatan kinerja dari PNS juga merupakan salah satu wujud dari pelaksanaan reformasi birokrasi.

Reformasi birokrasi merupakan upaya dalam melakukan pembaharuan dan perubahan sistem penyelenggaraan pemerintahan menyangkut aspek-aspek kelembagaan, ketatalaksanaan dan sumber daya manusia aparatur. Reformasi birokrasi tidak lepas dari reformasi manajemen sumber daya manusia (SDM) aparatur sehingga seorang aparatur sipil negara dibebankan serangkaian kewajiban untuk bersikap dan menjalankan tugasnya dengan profesional sebagai bagian dari tanggung jawabnya untuk menjalankan proses birokrasi.

Guna terwujudnya PNS sebagai sumber daya manusia yang berkontribusi dalam reformasi birokrasi, seorang PNS memiliki kewajiban untuk melakukan pengelolaan dan pengembangan yang diiringi dengan kewajiban untuk mempertanggungjawabkan kinerja dalam pelaksanaan manajemen aparatur sipil negara dengan penerapan norma, prosedur standar, dan kriteria. Sepanjang reformasi birokrasi di bidang sumber daya manusia tidak lepas dari pemberian sanksi dan pemberhentian seorang PNS akibat sebab-sebab tertentu, salah satunya berdasarkan kinerja PNS yang tidak mencapai target.

Penilaian kinerja PNS termaktub dalam pasal 77 angka (6) Undang-Undang Nomor 5 Tahun 2014 tentang Aparatur Sipil Negara, pasal ini menyebutkan bahwa seorang PNS yang penilaian kinerjanya tidak sesuai target yang telah ditetapkan maka dikenakan sanksi berupa sanksi administratif hingga pemberhentian. Pada dasarnya kinerja PNS merupakan hasil dan penilaian kerja yang dilakukan oleh PNS secara kualitas dan kuantitas yang telah dicapai oleh seseorang PNS dalam melaksanakan tugas, kewenangan, kewajiban dan tanggung jawab yang telah diberikan. ${ }^{1}$

Penilaian dilakukan berdasarkan perencanaan kinerja dengan memperhatikan target, pencapaian, hasil serta perilaku PNS, sehingga penilaian ini digunakan sebagai tolak ukur untuk melihat apakah seorang PNS telah mencapai target kerja yang telah dilakukan yang dilakukan untuk menjamin objektivitas prestasi kerja.

Pengaturan lebih lanjut mengenai instrumen penilaian kinerja yang tertuang dalam Peraturan Pemerintah Nomor 30 Tahun 2019 tentang Penilaian Kinerja Pegawai Negeri Sipil sebagai rangkaian dalam sistem manajemen kinerja PNS dengan penggunaan

1 A.A. Anwar Prabu Mangkunegara, (2000), Manajemen Sumber Daya Manusia, Bandung; Remaja Rosdakarya. Hlm. 67. 
instrumen penyusunan Sasaran Kinerja Pegawai (SKP). ${ }^{2}$

Pelaksanaan pengukuran SKP dilakukan dengan melakukan perbandingan antara realisasi kinerja dengan target yang ditetapkan dan dilakukan penilaian kinerja yang terdiri atas penilaian SKP dan penilaian perilaku kerja dengan menggunakan data serta hasil pengukuran yang bersifat kuantitatif.

Konsekuensi dari adanya penilaian kinerja PNS dalam PP 30/2019 adalah adanya ancaman sanksi administrasi hingga pemberhentian kepada pejabat tertentu jika tidak memenuhi target yang ditetapkan yang tertera dalam pasal 56 PP 30/2019 yaitu:

"Pejabat pimpinan tinggi, pejabat administrasi, dan pejabat fungsional yang tidak memenuhi target kinerja dapat dikenakan sanksi administrasi sampai dengan pemberhentian".

Ditetapkannya PP 30/2019 ini melengkapi manajemen aparatur sipil negara yang terdiri atas PNS dan PPPK, lebih khususnya mengenai penilaian kinerja PNS. Adapun pengaturan penilaian kinerja PPPK tertuang secara rinci dalam pasal 35 Peraturan Pemerintah Nomor 49 Tahun 2018 tentang Manajemen Pegawai Pemerintah Dengan Perjanjian Kerja. Perbedaan diantara PP 30/2019 dan PP 49/2018 adalah subyek yang memiliki kewenangan untuk melakukan penilaian kinerja dan dasar atau instrumen penilaian. Adapun pihak yang berwenang untuk melakukan penilaian kinerja terhadap PNS adalah Tim Penilai Kinerja PNS yang dibentuk oleh pejabat yang berwenang dengan data dan hasil pengukuran yang ditetapkan sedangkan bagi PPPK yang berwenang untuk melakukan penilaian kinerja adalah pejabat yang bersangkutan berdasarkan perjanjian kerja yang telah ditetapkan antara pejabat pembina kepegawaian dengan pegawai PPPK.

Urgensi penelitian ini adalah untuk menganalisis ratio legis penilaian kinerja PNS yang tidak memenuhi target kinerja yang berdampak pada pemberian sanksi baik berbentuk administrative maupun pemberhentian PNS serta untuk menganalisis implikasi hukum pemberhentian PNS atas dasar penilaian kinerja. Adanya bentuk penilaian kinerja PNS atas lahirnya PP 30/2019 memberikan pertimbangan bagi peneliti untuk menentukan judul "Pemberhentian Pegawai Negeri Sipil berdasarkan Penilaian Kinerja dalam PP Nomor 30 Tahun tentang Penilaian Kinerja PNS".

Terhadap latarbelakang di atas, ditarik dua rumusan masalah sebagai berikut: (1) Apa ratio legis dari pemberhentian PNS berdasarkan penilaian kinerja dalam PP Nomor 30 Tahun 2019 tentang Penilaian Kerja? (2) Apa implikasi hukum dari pemberhentian PNS berdasarkan penilaian

\footnotetext{
${ }^{2}$ Pasal 3 angka (1) PP 30 Tahun 2019 tentang Penilaian Kinerja PNS
} 
kinerja dalam PP Nomor 30 Tahun 2019 tentang Penilaian Kinerja?

\section{PEMBAHASAN}

Rasio Legis pemberhentian PNS

Berdasarkan Penilaian Kinerja Dalam PP

Nomor 30 Tahun 2019 tentang Penilaian

Kerja Pegawai Negeri Sipil

Pegawai merupakan tenaga kerja manusia jasmaniah maupun rohaniah (mental dan pikiran) yang senantiasa dibutuhkan dan oleh karena itu menjadi salah satu modal pokok dalam usaha kerja sama untuk mencapai tujuan tertentu (organisasi). Selain itu, Pegawai adalah orang-orang yang dikerjakan dalam suatu badan tertentu, baik di lembagalembaga pemerintah maupun dalam badanbadan usaha. ${ }^{3}$

Pasal 4 ayat (1) UUD NRI Tahun 1945 mengatur bahwa Presiden Republik Indonesia memegang kekuasaan pemerintahan menurut Undang Undang Dasar. Dengan kata lain, Presiden merupakan penyelenggara negara (eksekutif) yang termasuk dalam salah satu lembaga tinggi negara. Dalam menjalankan pemerintahan negara, kekuasaan dan tanggungjawab sepenuhnya berada pada Presiden.

Dalam Alinea Kedua UUD NRI Tahun 1945 telah tercantum pula tugas konstitusional Pemerintah Negara Republik Indonesia adalah melindungi segenap bangsa Indonesia dan seluruh tumpah darah
Indonesia dan untuk memajukan kesejahteraan umum, mencerdaskan kehidupan bangsa, dan ikut melaksanakan ketertiban dunia berdasarkan kemerdekaan, perdamaian abadi dan keadilan sosial. ${ }^{4}$

Pemerintahan Negara yang diperintahkan oleh UUD NKRI Tahun 1945 adalah pemerintahan demokratis, desentralistis, bersih dari praktek $\mathrm{KKN}$, serta yang mampu menyelenggarakan pelayanan publik secara adil. Ketentuan tentang bentuk pemerintahan seperti tersebut tertuang dalam berbagai Peraturan Perundang-undangan sebagai pelaksanaan dari UUD NKRI Tahun 1945 yang merupakan sublimasi cita-cita luhur bangsa sebagaimana tercantum dalam UUD NKRI Tahun 1945 tentang tata pemerintahan yang baik atau good governance. Dalam rangka menyelengarakan pemerintahan tersebut, perlu dibangun aparatur negara yang profesional, bebas dari intervensi politik, bersih praktek KKN, berintegritas tinggi, serta berkemampuan dan kinerja tinggi.

Pemberhentian Pegawai Negeri Sipil (PNS) dapat diberhentikan dengan tidak hormat karena beberapa alasan, alasan tersebut berupa:

a. Melakukan penyelewengan terhadap Pancasila dan Undang-Undang Dasar Negara Republik Indonesia Tahun 1945 ;

A.W. Widjaja, (2006), Administrasi Kepegawaian, Jakarta: Rajawali. Hlm 15.

Alinea Kedua UUD NRI Tahun 1945 
b. Dihukum penjara atau kurungan berdasarkan putusan pengadilan yang telah memiliki kekuatan hukum tetap karena melakukan tindak pidana kejahatan jabatan atau tindak pidana kejahatan yang ada hubungannya dengan jabatan dan/atau pidana umum;

c. Menjadi anggota dan/atau pengurus partai politik; atau

d. Dihukum penjara berdasarkan putusan pengadilan yang telah memiliki kekuatan hukum tetap karena melakukan tindak pidana dengan pidana penjara paling singkat 2 (dua) tahun dan pidana yang dilakukan dengan berencana.

Selain itu pemberhentian PNS dapat diberhentikan secara sementara, jika: ${ }^{5}$

a. Diangkat menjadi pejabat negara;

b. Diangkat menjadi komisioner atau anggota lembaga nonstruktural; atau

c. Ditahan karena menjadi tersangka tindak pidana.

Jabatan yang diberikan kepada PNS merupakan kepercayaan dari negara yang harus dijalankan dengan sebaik-baiknya, jika terdapat PNS yang melakukan penyelewengan atau pelanggaran terhadap Pancasila dan Undang-undang Dasar Negara Republik Indonesia tahun 1945 atau terbukti melakukan tindak pidana dan dihukum penjara atau kurungan berdasarkan putusan pengadilan yang tetap, maka Pegawai Negeri Sipil tersebut harus diberhentikan secara tidak hormat, karena menyalahgunakan kepercayaan yang diberikan oleh negara.

PNS yang diberhentikan secara tidak hormat tidak berhak menerima jaminan pensiun. Meskipun secara eksplisit tidak diatur dalam undang-undang nomor 5 tahun 2014 tentang Aparatur Sipil Negara, namun secara implisit di dalam pasal 91 ayat (2) 5 tahun 2014 tentang Aparatur Sipil Negara menjelaskan bahwa PNS diberikan jaminan pensiun apabila:

a. Meninggal dunia;

b. Atas permintaan sendiri dengan usia dan masa kerja tertentu;

c. Mencapai batas usia pensiun;

d. Perampingan organisasi atau kebijakan pemerintah yang mengakibatkan pensiun dini; atau

e. Tidak cakap jasmani dan/atau rohani sehingga tidak dapat menjalankan tugas dan kewajiban.

Maka dapat disimpulkan bahwa, PNS yang diberhentikan secara tidak hormat tidak berhak menerima jaminan pensiun, karena PNS yang diberhentikan secara tidak hormat karena dianggap PNS tersebut menyalahgunakan kepercayaan yang diberikan oleh negara.

\footnotetext{
5 Pasal 88 Undang-undang Nomor 5 Tahun 2014 tentang Aparatur Sipil Negara.
} 
Selain diatur di dalam undang-undang nomor 5 tahun 2014 tentang aparatur sipil negara mengenai penilaian kinerja pegawai negeri sipil, juga di atur lebih khusus di dalam peraturan pemerintah nomor 30 tahun 2019 tentang penilaian kinerja pegawai negeri sipil. Di dalam peraturan pemerintah nomor 30 tahun 2019 menyatakan bahwa pejabat yang berhak menilai kinerja PNS adalah atasan langsung PNS yang dinilai dengan ketentuan paling rendah pejabat pengawas atau pejabat lain yang diberi pendelegasian kewenangan. ${ }^{6}$ Proses penilaian tersebut, pejabat penilai kinerja PNS berhak membentuk tim penilai yang berwenang untuk memberikan pertimbangan kepada pejabat pembina kepegawaian mengenai usulan pengangkatan, pemindahan, dan pemberhentian dalam jabatan, pengembangan kompetensi, serta pemberian penghargaan bagi PNS.

Proses penilaian kinerja PNS dilakukan harus berdasarkan prinsip: ${ }^{7}$
a. Objektif;
b. Terukur;
c. Akuntabel;
d. Partisipatif; dan
e. Transparan;

Penilaian dapat dikatakan objektif apabila penilaian terhadap pencapaian yang dilakukan oleh pejabat penilai kinerja PNS. Adapun yang dimaksud dengan 'objektif' adalah penilaian terhadap pencapaian kinerja sesuai dengan keadaan yang sebenarnya tanpa dipengaruhi oleh pandangan atau penilaian subjektif pribadi dari pejabat penilai kinerja PNS. Yang dimaksud dengan "terukur" adalah penilaian kinerja yang dapat diukur secara kuantitatif dan kualitatif. Huruf c Yang dimaksud dengan "akuntabel" adalah seluruh hasil penilaian kinerja harus dapat dipertan ggungj awabkan kepada pejabat yang berwenang. Selanjutnya, Yang dimaksud dengan "partisipatif' adalah seluruh proses Penilaian Kinerja dengan melibatkan secara aktif antara pejabat penilai kinerja PNS dengan PNS yang dinilai. Huruf e Yang dimaksud dengan "transparan" adalah seluruh proses dan hasil penilaian pretasi kerja bersifat terbuka dan tidak bersifat rahasia.

Menganalisis Ratio legis PP Nomor 30 Tahun 2019 Tentang Penilaian Kinerja Pegawai Negeri Sipil tidak terlepas dari sejarah terbentuknya penilaian kinerja itu sendiri. Analisis dari penulis terkait dengan adanya PP No. 30 Tahun 2019 merupakan amanat dari ketentuan Pasal 78 UU 5 Tahun 2014 Aparatur Sipil Negara, yaitu Ketentuan lebih lanjut mengenai penilaian kinerja diatur dengan Peraturan Pemerintah.

Selain itu dapat dilihat pula bahwa ketentuan pasal 230 PP 11 Tahun 2017 Tentang Manajemen Pegawai Negeri Sipil

\footnotetext{
6 Pasal 1 Angka 8 dan Angka 9 Peraturan Pemerintah Nomor 30 Tahun 2019 tentang Penilaian Kinerja Pegawai Negeri Sipil.

7 Pasal 4 Peraturan Pemerintah Nomor 30 Tahun 2019 tentang Penilaian Kinerja Pegawai Negeri Sipil.
} 
juga mengatur bahwa Ketentuan lebih lanjut mengenai penilaian kinerja PNS dan disiplin PNS diatur dengan Peraturan Pemerintah. Maka atas dua peraturan perundang-undangan yang tingkatannya berbeda tersebut (Undangundang dan Peraturan Pemerintah), mengamanatkan atau memberikan wewenang secara atributif kepada Pemerintah untuk segera membentuk Peraturan Pemerintah yang mengatur secara teknis tentang penilaian kinerja PNS.

Sehingga pada pada tanggal 29 April 2019 disahkan PP No. 30 Tahun 2019. Hal tersebut juga dijustifikasi pada konsideran menimbang pada PP No. 30 Tahun 2019 yang menyebut "bahwa untuk melaksanakan ketentuan Pasal 78 Undang-Undang Nomor 5 Tahun 2014 tentang Aparatur Sipil Negara perlu menetapkan Peraturan Pemerintah tentang Penilaian Kinerja Pegawai Negeri Sipil".

Disahkannya PP Nomor 30 Tahun 2019 tentang Penilaian Kerja secara yuridis berdampak hukum pada tidak berlakunya peraturan perundang-undangan sejenis lainnya yang sifatnya horizontal. ${ }^{8}$

Sebelumnya, telah ada Pemerintah Nomor 46 Tahun 2011 tentang Penilaian Prestasi Kerja Pegawai Negeri Sipil (Lembaran Negara Republik Indonesia Tahun 2011 Nomor 121, Tambahan Lembaran Negara Republik Indonesia Nomor 5258). Namun PP tersebut secara tegas telah dicabut semenjak disahkannya PP Nomor 30 Tahun 2019 Tentang Penilaian Kinerja.

Penulis mengkaji terdapat perbedaan antara PP Nomor 46 Tahun 2011 dengan PP Nomor 30 Tahun 2019 yakni sebagai berikut:

Tabel 2: Perbedaan antara PP Nomor 46 Tahun 2011 dengan PP Nomor 30 Tahun 2019

\begin{tabular}{|r|l|l|l|}
\hline No & \multicolumn{1}{|c|}{ Poin Perbedaan } & PP Nomor 46 Tahun 2011 & PP Nomor 30 Tahun 2009 \\
\hline 1 & Penggunaan Istilah & Prestasi Kerja & Kinerja PNS \\
\hline 2 & $\begin{array}{l}\text { Sasaran } \\
\text { Pegawai }\end{array}$ & $\begin{array}{l}\text { Kencana kerja dan target yang } \\
\text { akan dicapai oleh seorang } \\
\text { PNS. }\end{array}$ & $\begin{array}{l}\text { hasil kerja yang dicapai oleh } \\
\text { setiap PNS pada organisasi/ } \\
\text { unit sesuai dengan SKP dan } \\
\text { Perilaku Kerja. }\end{array}$ \\
\hline 3 & Target & $\begin{array}{l}\text { jumlah beban kerja yang } \\
\text { akan dicapai }\end{array}$ & $\begin{array}{l}\text { jumlah hasil kerja yang akan } \\
\text { dicapai }\end{array}$ \\
\hline 4 & $\begin{array}{l}\text { Sasaran } \\
\text { Pegawan (SKP) }\end{array}$ & $\begin{array}{l}\text { Memuat kinerja utama dan } \\
\text { dapat memuat kinerja } \\
\text { tambahan, kinerja utama dan } \\
\text { kinerja tambahan paling } \\
\text { sedikit memuat: } \\
\text { a. Indikator } \\
\text { individu; } \\
\text { b. Target kinerja. }\end{array}$ \\
\hline
\end{tabular}

8 Berdasarkan asas lex posteriori derograt legi periori, yakni hukum yang baru mengenyampingkan hukum yang lama. 


\begin{tabular}{|c|c|c|c|}
\hline 5 & Penyusunan SKP & $\begin{array}{l}\text { didasarkan pada rencana } \\
\text { kerja tahunan instansi. }\end{array}$ & $\begin{array}{l}\text { memperhatikan: } \\
\text { a. perencanaan strategis } \\
\text { Instansi Pemerintah; } \\
\text { b. perjanjian kinerja; } \\
\text { c. organisasi dan tata kerja; } \\
\text { d. uraian jabatan; dan/atau } \\
\text { b. SKP atasan langsung. }\end{array}$ \\
\hline 6 & Aspek Perilaku Kerja & $\begin{array}{l}\text { a. orientasi pelayanan; } \\
\text { b. integritas; } \\
\text { c. komitmen; } \\
\text { d. disiplin; } \\
\text { e. kerja sama; } \\
\text { f. kepemimpinan. }\end{array}$ & $\begin{array}{l}\text { a. orientasi pelayanan; } \\
\text { b. komitmen; } \\
\text { c. inisiatif kerja; } \\
\text { d. kerja sama; } \\
\text { g. kepemimpinan }\end{array}$ \\
\hline 7 & Penilaian & $\begin{array}{l}\text { dilakukan melalui } \\
\text { pengamatan oleh pejabat } \\
\text { penilai dan dapat } \\
\text { mempertimbangkan } \\
\text { masukan dari pejabat penilai } \\
\text { lain yang setingkat di } \\
\text { lingkungan unit kerja } \\
\text { masing-masing. }\end{array}$ & $\begin{array}{l}\text { a. Penilaian Perilaku Kerja } \\
\text { dilakukan oleh Pejabat } \\
\text { Penilai Kinerja PNS, dan } \\
\text { dapat berdasarkan } \\
\text { penilaian rekan kerja } \\
\text { b. setingkat dan/atau } \\
\text { bawahan langsung. }\end{array}$ \\
\hline \multirow{4}{*}{8} & \multirow{4}{*}{ Bobot Penilaian } & $\begin{array}{l}\text { 1. Unsur SKP } 60 \% \\
\text { 2. Perilaku kerja } 40 \%\end{array}$ & $\begin{array}{l}\text { 1. Unsur SKP } 70 \% \text { dan } \\
\text { perilaku kerja } 30 \% \\
\text { 2. Unsur SKP } 60 \% \text { dan } \\
\text { perilaku kerja } 40 \% \%^{*} \\
\text { *) bagi Instansi Pemerintah } \\
\text { yang menerapkan } \\
\text { penilaian } 360^{\circ}\end{array}$ \\
\hline & & $\begin{array}{l}\text { Jika melebihi target maka } \\
\text { penilaian SKP dapat lebih } \\
\text { dari } 100\end{array}$ & $\begin{array}{l}\text { Realisasi kinerja PNS yang } \\
\text { melebihi Target kinerja, nilai } \\
\text { capaian kinerja paling tinggi } \\
\text { pada angka } 120 \text {. }\end{array}$ \\
\hline & & $\begin{array}{l}\text { Penilaian prestasi kerja PNS } \\
\text { dilaksanakan oleh pejabat } \\
\text { penilai sekali dalam } 1 \text { tahun. }\end{array}$ & $\begin{array}{l}\text { Penilaian kinerja didasarkan } \\
\text { pada pengukuran kinerja } \\
\text { yang dapat dilakukan setiap } \\
\text { bulan, triwulanan, } \\
\text { semesteran, atau tahunan } \\
\text { serta didokumentasikan } \\
\text { dalam dokumen pengukuran } \\
\text { kinerja sesuai kebutuhan } \\
\text { organisasi. }\end{array}$ \\
\hline & & $\begin{array}{l}\text { Nilai prestasi kerja PNS } \\
\text { dinyatakan dengan angka } \\
\text { dan sebutan: } \\
\text { a. } 91-\text { ke atas (sangat baik) } \\
\text { b. } 76-90 \text { (baik). } \\
\text { c. } 61-75 \text { (cukup) } \\
\text { d. } 51-60 \text { (kurang) } \\
\text { e. } 50 \text { ke bawah (buruk) }\end{array}$ & $\begin{array}{l}\text { Penilaian Kinerja PNS } \\
\text { dinyatakan dengan angka } \\
\text { dan sebutan/predikat: a. } \\
\text { Sangat Baik (nilai } 110 \leq 120 \\
\text { dan Menciptakan Ide Baru } \\
\text { Dan/Atau Cara Baru dalam } \\
\text { peningkatan kinerja yang } \\
\text { memberi manfaat bagi } \\
\text { organisasi atau negara) b. }\end{array}$ \\
\hline
\end{tabular}




\begin{tabular}{|l|l|l|}
\hline & & Baik, nilai $90<\mathrm{x}<120 \mathrm{c}$. \\
& & Cukup, nilai $70 \mathrm{x}<90 \mathrm{~d}$. \\
& Kurang, nilai $50<\mathrm{x}<70 \mathrm{e}$. \\
& Sangat Kurang, nilai $<50$ \\
\hline
\end{tabular}

Selain dari 8 (delapan) poin perbedaan antara perbedaan antara PP Nomor 46 Tahun 2011 dengan PP Nomor 30 Tahun 2019, juga terdapat beberapa hal baru yang diatur dalam PP Nomor 30 Tahun 2019 yang mana sebelumnya tidak di atur oleh PP Nomor 46 Tahun 2011, yakni sebagai berikut:
a. Tim penilai kinerja pns
b. pemantauan kinerja
c. bimbingan dan konseling kinerja
d. pemeringkatan kinerja
e. sistem informasi kinerja pns
f. pengelola kinerja
g. penghargaan
h. sanksi

Pada kajian ratio legis ini, penulis juga mengaitkan dengan program nawa cita dari Presiden Joko Widodo yang terdiri atas:

a. Menolak Negara Lemah dengan Melakukan Reformasi Sistem dan Penegakan Hukum yang Bebas Korupsi, Bermartabat, dan Terpercaya.

b. Membangun Indonesia dari Pinggiran dengan Memperkuat Daerah-Daerah dan Desa dalam Kerangka Negara Kesatuan.

c. Memperteguh Kebhinnekaan dan Memperkuat Restorasi Sosial Indonesia. d. Menghadirkan Kembali Negara untuk Melindungi Segenap Bangsa dan Memberikan Rasa Aman pada Seluruh Warga.

e. Membuat Pemerintah Tidak Absen dengan Membangun Tata Kelola Pemerintahan yang Bersih, Efektif, Demokratif, dan Terpercaya.

f. Meningkatkan Kualitas Hidup Manusia Indonesia.

g. Mewujudkan Kemandirian Ekonomi dengan Menggerakkan Sektor-Sektor Strategis Ekonomi Domestik.

h. Melakukan Revolusi Karakter Bangsa.

i. Meningkatkan Produktivitas Rakyat dan Daya Saing di Pasar Internasional.

Beberapa di antara sembilan poin yang terdapat dalam nawa cita presiden Joko Widodo telah diwujudkan dalam pembentukan peraturan perundang-undagan yang salah satunya juga pada PP Nomor 30 Tahun 2019. Utamanya pada poin huruf e yaitu "Membuat Pemerintah Tidak Absen dengan Membangun Tata Kelola Pemerintahan yang Bersih, Efektif, Demokratif, dan Terpercaya". Tatakelola Pemerintahan yang dimaksud dalam nawa cita sebenarnya juga merupakan tatakelola Pemerintahan yang dimaksud dalam Asasasas Umum Pemerintahan Yang Baik. 
Implikasi Hukum Dari Pemberhentian PNS Berdasarkan Penilaian Kinerja Dalam PP Nomor 30 Tahun 2019 Tentang Penilaian Kinerja

Salah satu indikator penilaian terhadap penyelenggaraan dan pelaksanaan pembangunan nasional dapat ditinjau berdasaarkan kesempurnaan Aparatur Sipil Negara (ASN) dimana Pegawai Negeri Sipil (PNS) sebagai inti penggeraknya.

Dalam Penjelasan Umum atas UndangUndang Nomor 5 Tahun 2014 tentang Aparatur Sipil Negara menyatakan bahwa dalam rangka mencapai tujuan nasional sebagaimana tercantum dalam alinea ke-4 Pembukaan Undang-Undang Dasar Negara Republik Indonesia Tahun 1945 (UUD 1945), diperlukan ASN yang professional, bebas dari intervensi politik, bersih dari praktik korupsi, kolusi dan nepotisme, mampu menyelenggarakan pelayanan publik bagi masayarakat dan mampu menjalankan peran sebagai perekat persatuan dan kesatuan bangsa berdasarkan Pancasila dan UUD 1945.

Tujuan pembangunan nasional sebagaimana yang tercantum dalam Pembukaan UUD 1945 yakni melindungi segenap bangsa Indonesia dan seluruh tumpah darah Indonesia, memajukan kesejahteraan umum, mencerdaskan kehidupan bangsa, dan ikut melaksanakan ketertiban dunia yang berdasarkan kemerdekaan, perdamaian abadi, dan keadilan sosial. Guna mencapai tujuan nasional tersebut, maka perlu adanya PNS yang penuh kesetiaan dan ketaatan kepada Pancasila, UUD NRI Tahun 1945, Negara dan Pemerintah, serta yang bermental baik, berwibawa, bersih, berkualitas tinggi dan sadar akan tanggung jawabnya sebagai unsur Abdi Negara dan Abdi Masyarakat yang bekerja untuk kepentingan masyarakat karenanya dalam pelaksanaan pembinaan Pegawai Negeri tidak hanya dilihat sebagai Aparatur Negara, namun juga sebagai warga Negara. ${ }^{9}$

Penegasan dalam Pembukaan UUD NRI Tahun 1945 merupakan bagian dari upaya untuk mencapai tujuan nasional, karenanya negara memerlukan sarana-prasarana yang mendukung, baik berupa sumber daya manusia maupun sarana yang berbentuk benda, karena negara tidak dapat melakukannya sendiri. ${ }^{10}$

Pegawai negeri mempunyai peranan sangat penting karena pegawai negeri merupakan unsur aparatur untuk menyelenggarakan pemerintahan dan pembangunan dalam rangka mencapai tujuan negara. Kelancaran pelaksanaan pemerintahan dan pembangunan itu utamanya tergantung pada kesempurnaan aparatur negara yang pada pokoknya

\footnotetext{
9 Djaenal Hoesen Koesoemahatmadja, (1993), Pokok-Pokok Hukum Tata Usaha Negara 2, Bandung; Citra Aditya Bakti. Hlm 159.

10 Muchsan, (1982), Hukum Kepegawaian, Jakarta; Bina Aksara. Hlm,12.
} 
tergantung juga dari kesempurnaan pegawai negeri sebagai bagian dari aparatur negara. ${ }^{11}$

Keberadaan PNS saat ini diatur dalam Undang-Undang Nomor 5 Tahun 2014 tentang Aparatur Sipil Negara dan Peraturan Pemerintah Nomor 11 Tahun 2017 tentang Manajemen PNS sebagai peraturan pelaksanaannya. UU ASN merupakan produk hukum yang berorientasi strategis untuk membangun aparatur negara agar lebih berdaya guna dan berhasil guna dalam mengemban tugas umum pemerintahan dan pembangunan nasional didasari pada semangat reformasi. ${ }^{12}$

Dalam melaksanakan tugasnya, setiap PNS mempunyai kewajiban serta kode etik dan kode prilaku yang harus ditaati dan dilaksanakan. Kewajiban serta kode etik dan kode perilaku PNS merupakan pedoman sikap tingkah laku dan perbuatan di dalam dan di luar kantor atau kedinasan. Salah satu tujuan taat dan patuh terhadap kewajiban serta kode etik dan kode prilaku kewajiban ialah untuk membentuk PNS yang bersih dari segala masalah hukum.

Dengan maksud untuk mendidik dan membina Pegawai Negeri Sipil, bagi mereka yang melakukan pelanggaran atas kewajiban dan larangan dikenakan sanksi berupa hukuman disiplin. ${ }^{13}$ Kewajiban serta kode etik dan kode prilaku yang dilanggar/tidak dilaksanakan dapat berdampak pada hilangnya status kepegawaian seorang PNS, yang berdampak pula pada hilangnya hak kepegawaiannya. Seperti diketahui, kedudukan PNS sangat penting sebagai unsur aparatur dan sebagai penggerak roda pemerintahan, namun tidak dapat dipungkiri seorang PNS dalam menjalankan tugas dan fungsinya dapat melakukan tindakantindakan yang bertentangan dengan kode etik dan kewajiban sebagai seorang PNS. Seorang PNS yang melakukan tindakan tersebut dapat dikenai sanksi administrastif sampai dengan pemberhentian.

Sanksi administrasi berbeda dengan sanksi pidana. Perbedaan antara sanksi administrasi dan sanksi pidana dapat dilihat dari tujuan pengenaan sanksi itu sendiri. Sanksi administrasi ditujukan kepada perbuatan pelanggarannya sedangkan sanksi pidana ditujukan kepada si pelanggar dengan memberi hukuman berupa nestapa. Sanksi administrasi dimaksudkan agar perbuatan pelanggaran itu dihentikan.

Sifat sanksi adalah "reparatoir" artinya memulihkan pada keadaan semula. Di samping itu perbedaan antara sanksi pidana dan sanksi administrasi ialah tindakan penegakan hukumnya. Sanksi administrasi

11 SF. Marbun dan Moh. Mahfud MD, (2000), Pokok-Pokok Hukum Administrasi Negara, Yogyakarta; Liberty, Hlm. 98.

12 Sri Hartini dan Tedi Sudrajat, (2017), Hukum Kepegawaian di Indonesia, Jakarta; Sinar Grafika. Hlm. 3.

13 M. Suparno, (1992), Rekayasa Pembangunan Watak dan Moral Bangsa, Jakarta; Purel Mundial. Hlm. 85. 
diterapkan oleh Pejabat Tata Usaha Negara tanpa harus melalui prosedur peradilan sedangkan sanksi pidana hanya dapat dijatuhkan oleh hakim pidana melalui proses peradilan. $^{14}$

Pada pembahasan sebelumnya telah penulis sebutkan bahwa PNS juga perlu untuk mengindahkan adanya ketentuan-ketentuan yang terdapat pada PP Nomor 30 Tahun 2019 Tujuan dari penilaian kerja sebagaimana yang dimaksud dalam PP Nomor 30 Tahun 2019 adalah Menjamin objektivitas pembinaan PNS yang didasarkan pada sistem prestasi dan sistem karier.

Implikasi terhadap adanya penilaian Prestasi Kerja PNS diharapkan dapat mewujudkan pegawai yang profesional dalam mendukung percepatan pelaksanaan reformasi birokrasi. Karena itu, setiap PNS harus memiliki rencana dan target kerja setiap tahunnya, sesuai bidang tugasnya berdasar ketentuan tersebut.

Selanjutnya Muchsan berpendapat bahwa Keberhasilan tindakan aparatur pemerintah diukur dari dua indikator sebagai berikut $:^{15}$

1. frekuensi timbulnya kerugian pada individu sebagai akibat perbuatan (aksi) aparat pemerintah.
2. bobot perlindungan hukum yang diberikan oleh pemerintah selaku penguasa kepada pihak individu.

Berdasar pada pendapat muchsan, penulis menganalisis bahwa 2 (dua) indikator tersebut sangat relevan bila dikaitkan dengan penilaian kinerja dari setiap PNS, karena pada dasarnya, PNS merupakan abdi negara yang wajib memberikan pelayanan optimal dan profesional kepada masyarakat.

Bila masyarakat dirugikan atas tindakan atau pelayanan dari PNS yang kurang optimal, maka dapat pula dikatakan bahwa Pemerintah tidak berhasil dalam menyelenggarakan Pemerintahan dalam suatu Negara. Terlebih pada era Presiden Joko Widodo yang menghendaki agar setiap PNS dapat meningkatkan fungsi pelayanan dari Pemerintah maka perlu dibuat aturan hukumnya, yaitu PP Nomor 30 Tahun 2019.

Data dari kementerian pemberdayaan aparatur negara menyebutkan bahwa terdapat beberapa permasalahan dalam kaitannya dengan sebelum disahkannya PP Nomor 30 Tahun 2019, yaitu sebagai berikut: ${ }^{16}$

1) Penilaian Prestasi Kerja belum dapat memotret kinerja PNS sesungguhnya;

14 Philipus M. Hadjon, dkk., (2008), Pengantar Hukum Administrasi Indonesia, Yogyakarta; Gadjah Mada University Press. Hlm. 247.

15 Muchsan, (1994), Beberapa Catatan Tentang Hukum Administrasi Negara dan Peradilan Administrasi Negara di Indonesia, Yogyakarta; Liberty. Hlm. 36.

$16 \ldots$ _. (17 Agustus 2019), Strategi Percepatan Persiapan Implementasi PP No. 30 Tahun 2019 Tentang Penilaian Kinerja PNS oleh Ketua Tim Kerja Optimalisasi Kinerja ASN, Diakses pada tanggal 5 November 2019, Dari Kementerian Pendayagunaan Aparatur Negara dan Reformasi Birokrasi: https://www.menpan.go.id/site/download/file/6164-7-strategi-percepatan-persiapan-implementasi-pp-no-30tahun-2019-tentang-penilaian-kinerja-pns-oleh-ketua-tim-kerja-optimalisasi-kinerja-asn, 
2) Penilaian prestasi kerja terkesan formalitas karena pegawai harus memiliki nilai Baik supaya bisa naik pangkat 4 tahun sekali;

3) Hello effect penilaian prestasi kerja dari atasan;

4) Kinerja pegawai tidak terkoneksi langsung dengan kinerja organisasi;

5) Kinerja atasan tidak dijabarkan ke dalam kinerja bawahan;

6) Penilaian kinerja dilakukan hanya setahun sekali, sehingga tidak dapat diketahui progress kinerja pegawai.

Terhadap permasalahan tersebut, terdapat beberapa tantangan setelah disahkannya PP Nomor 30 Tahun 2019, yaitu: ${ }^{17}$

1) Perubahan mindset dari bekerja menjadi berkinerja dan penilaian yang obyektif;

2) Perlunya tools manajemen kinerja yang efektif dan implementable;

3) Waktu transisi implementasi PP 30 Tahun 2019 di tahun 2021 tersisa 14 bulan efektif.

Setiap PNS dituntut untuk dapat menghadapi tantangan tersebut serta meningkatkan kreatifitas dalam bekerja guna dapat memenuhi target kinerja. Adanya pasal 56 PP Nomor 30 Tahun 2019 yakni "Pejabat pimpinan tinggi, pejabat administrasi, dan pejabat fungsional yang tidak memenuhi Target kinerja dapat dikenakan sanksi administrasi sampai dengan pemberhentian." Maka dengan adanya ketentuan tersebut PNS dapat dikenakan sanksi administratif hingga pemberhentian bila tidak mampu memenuhi target kinerja.

Analisis penulis terkait dengan hal di atas adalah salah satu contoh penerapan dari law as a tool of social engineering atau oleh Mochtar Kusumatmadja sebagai teori hukum pembangunan yang berarti bahwa hukum sebagai alat untuk merekayasa sosial.

"Pendayagunaan hukum sebagai sarana untuk merekayasa masyarakat menuju skenario kebijakan pemerintah (eksekutif) amatlah terasa diperlukan oleh negara-negara berkembang, jauh melebihi kebutuhan negara-negara industri maju yang telah mapan, karena negara-negara maju telah memiliki mekanisme hukum yang telah "jalan" untuk mengakomodasi perubahanperubahan di dalam masyarakat, sedangkan negara-negara berkembang tidaklah demikian. $^{18}$

Teori hukum pembangunan menurut penulis sangat relevan bila digunakan dalam meningkatkan profesionalitas dari PNS di Indonesia.

\section{KESIMPULAN}

Rasio Legis pemberhentian PNS Berdasarkan Penilaian Kinerja Dalam PP Nomor 30 Tahun 2019 tentang Penilaian

17 Ibid.

18 Mochtar Kusuma Atmaja, dalam Soetandyo Wignjosoebroto, (1994), Dari Hukum Kolonial Ke Hukum Nasional: Dinamika Sosial Politik dan Perkembangan Hukum di Indonesia, Jakarta; Rajawali Press. Hlm 231. 
Kerja Pegawai Negeri Sipil adalah untuk menyempurnakan aturan yang sebelumnya telah berlaku, yaitu PP Nomor 46 Tahun 2011.

Selain itu, PP Nomor 30 Tahun 2019 merupakan amanat atau aturan pelaksana dari Pasal 78 UU 5 Tahun 2014 Aparatur Sipil Negara, yaitu Ketentuan lebih lanjut mengenai penilaian kinerja diatur dengan Peraturan Pemerintah. Serta pada pasal 230 PP 11 Tahun 2017 Tentang Manajemen Pegawai Negeri Sipil juga mengatur bahwa Ketentuan lebih lanjut mengenai penilaian kinerja PNS dan disiplin PNS diatur dengan Peraturan Pemerintah.

Implikasi Hukum Dari Pemberhentian PNS Berdasarkan Penilaian Kinerja Dalam PP Nomor 30 Tahun 2019 Tentang Penilaian Kinerja adalah sebagai salah satu bentuk law as a tool of social engineering atau hukum sebagai alat rekayasa sosial, utamanya pada pasal 56 yaitu "Pejabat pimpinan tinggi, pejabat administrasi, dan pejabat fungsional yang tidak memenuhi Target kinerja dapat dikenakan sanksi administrasi sampai dengan pemberhentian. "Sehingga dengan adanya PP Nomor 30 Tahun 2019 dapat meningkatkan profesionalisme dan kreatifitasnya sehingga mampu memenuhi target kinerja.

\section{DAFTAR PUSTAKA}

\section{Peraturan Perundang-Undangan}

Undang-Undang Dasar Negara Republik Indonesia Tahun 1945

Undang-undang Nomor 5 Tahun 2014 tentang Aparatur Sipil Negara
Peraturan Pemerintah 30 Tahun 2019 tentang Penilaian Kinerja Pegawai Negeri S

\section{Buku}

A.A. Anwar Prabu Mangkunegara, (2000), Manajemen Sumber Daya Manusia, Bandung; Remaja Rosdakarya.

A.W. Widjaja, (2006), Administrasi Kepegawaian, Jakarta; Rajawali.

Djaenal Hoesen Koesoemahatmadja, (1993),

Pokok-Pokok Hukum Tata Usaha

Negara 2, Bandung; Citra Aditya Bakti.

M. Suparno, (1992), Rekayasa Pembangunan

Watak dan Moral Bangsa, Jakarta; Purel Mundial.

Mochtar Kusuma Atmaja, dalam Soetandyo Wignjosoebroto, (1994), Dari Hukum

Kolonial Ke Hukum Nasional:

Dinamika Sosial Politik dan Perkembangan Hukum di Indonesia, Jakarta; Rajawali Press.

Muchsan, (1982), Hukum Kepegawaian, Jakarta; Bina Aksara.

Muchsan, (1994), Beberapa Catatan Tentang

Hukum Administrasi Negara dan Peradilan Administrasi Negara di Indonesia, Yogyakarta; Liberty.

Philipus M. Hadjon, dkk, (2008), Pengantar Hukum Administrasi Indonesia, Yogyakarta; Gadjah Mada University Press.

SF. Marbun dan Moh. Mahfud MD, (2000), Pokok-Pokok Hukum Administrasi Negara, Yogyakarta; Liberty.

Sri Hartini dan Tedi Sudrajat, (2017), Hukum Kepegawaian di Indonesia, Jakarta: Sinar Grafika. 